Vol. 9 No. 2, December 2018

\title{
ANALISIS PENGARUH KOMITMEN AKAD TERHADAP PENGEMBALIAN PEMBIAYAAN PADA BANK SYARIAH (Studi Kasus Bank Syariah di Kota Bogor)
}

\author{
Martha Kirana \\ Universitas Ibn Khaldun Bogor \\ Email: kirana.m07@gmail.com
}

\begin{abstract}
Abstrak
Penelitian ini bertujuan untuk mengetahui faktor-faktor yang mempengaruhi tingkat kepatuhan nasabah pembiayaan (komitmen) terhadap akad pembiayaan di bank syariah kota Bogor, dan bagaimana pengaruh penerapan komitmen akad terhadap pengembalian pembiayaan di bank syariah kota Bogor. Data yang digunakan addalah data primer dan sekunder, instrumen yang digunakan adalah angket dengan pengukuran skala likert. Metode pada penelitian ini menggunakan analisis regresi linear sederhana dengan alat batu SPSS (Statistical Package for the Social Sciences). Hasil penelitian ini adalah H0 ditolak dan H1 diterima. karena konstan pada penelitian ini adalah sebesar -0.752 yang berarti bahwa pengembalian pembiayaan (Y) memiliki angka -0.752 apabila nilai $X$ (komitmen akad) adalah sama dengan 0. Koefisien regresi X (komitmen akad) menunjukkan angka 0,939 yang berarti bahwa setiap kenaikan 1 persen komitmen akad maka akan meningkatkan pengembalian pembiayaan sebesar 0.939 persen dengan tingkat signifikansi sebesar 15.204 ( $\mathrm{t}$ hitung) > 2.052 ( $\mathrm{t}$ tabel) ang berarti bahwa terdapat pengaruh positif dan signifikan komitmen akad terhadap pengembalian pembiayaan.
\end{abstract}

Keywords: Komitmen Akad, Pembiayaan, Bank Syariah Kota Bogor

\section{Pendahuluan}

Tujuh puluh persen sampai 80 persen volume usaha perbankan adalah dalam bentuk pembiayaan. Pembiayaan merupakan salah satu kegiatan yang sangat penting dan utama dalam perbankan. Pendapatan dari pembiayaan berupa bagi hasil merupakan fee based income bagi bank. Apabila pembiayaan tidak dapat dikelola dan di'maintain' dengan baik oleh pelaku perbankan, maka risiko yang akan dihadapi oleh pihak perbankan adalah risiko kredit macet. Oleh karenanya kredit macet merupakan salah satu masalah penting yang dihadapi dalam pemberian pembiayaan. Besar kecilnya risiko kredit macet dapat diukur melalui rasio NPF (Non Performing Financing) pada perbankan syariah yang juga menjadi salah satu indikator untuk menilai tingkat kesehatan bank. Menurut Siamat (2005), NPF atau pembiayaan bermasalah adalah pinjaman yang mengalami kesulitan pelunasan akibat adanya faktor kesengajaan dan atau karena faktor eksternal diluar kemampuan/kendali nasabah peminjam. Sehingga, besar kecilnya NPF akan menunjukkan kinerja suatu bank dalam pengelolaan dana yang disalurkan. Apabila porsi pembiayaan bermasalah ini membesar, maka hal tersebut pada akhirnya akan berdampak pada penurunan pendapatan yang akan diperoleh bank dan akan mempengaruhi tingkat profitabilitas bank syariah (Ali, 2004). 


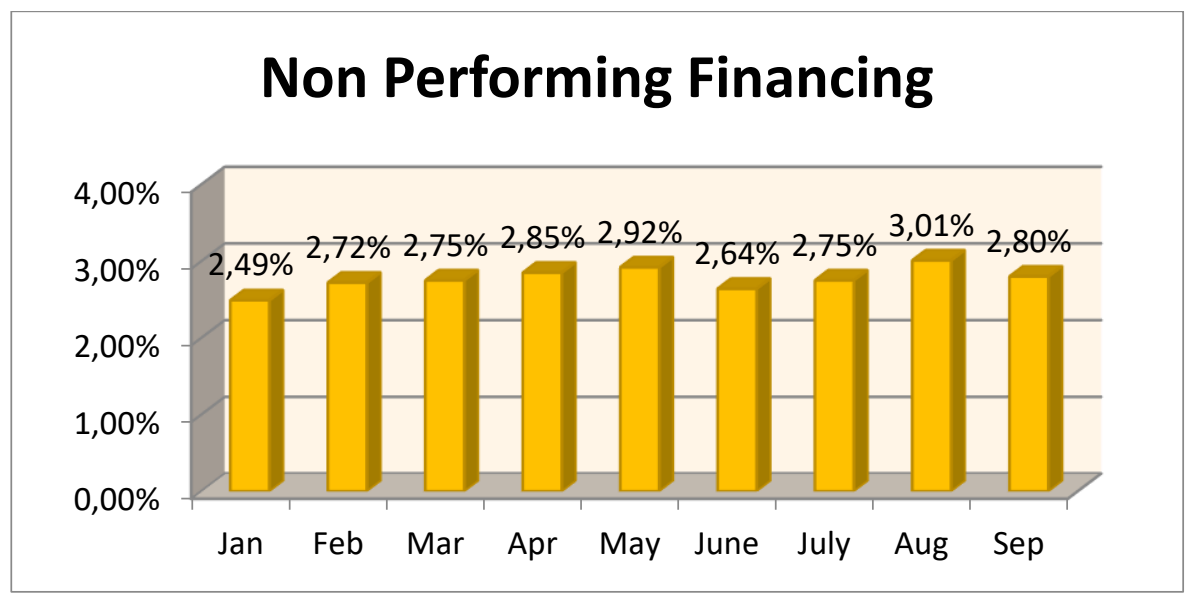

Gambar 1. Non Performing Financing Perbankan Syariah 2013

Sumber: Statistik Perbankan Syariah per September 2013

Gambar 1 diatas menjelaskan perkembangan NPF perbankan syariah di Indonesia pada tahun 2013 sampai pada bulan September. Berdasarkan gambar tersebut dapat dilihat bahwa NPF perbankan syariah terlihat semakin meningkat dibandingkan bulan Januari. NPF tertinggi di tahun 2013 terjadi pada bulan Agustus sebesar 3.01\%. Meskipun rasio NPF perbankan syariah masih dibawah batas yang disyaratkan oleh Bank Indonesia, tentunya peningkatan rasion NPF turut menjadi pekerjaan rumah bagi bank syariah untuk dapat mempertahankan rasio NPF yang kecil. Oleh karenanya masyarakat pun akan merasa aman untuk menitipkan dananya di bank syariah.

Untuk menekan rasio NPF agar tidak mengalami peningkatan secara drastic maka ada beberapa hal yang dapat dilakukan oleh pihak perbankan sebelum melakukan pembiayaan yaitu dengan melakukan analisis kelayakan pembiayaan. Penilaian kelayakan pembiayaan pada bank syariah, selain didasarkan pada business wise, juga harus mempertimbangkan syariah wise. Artinya, bisnis tersebut layak dibiayai dari segi usahanya dan acceptable dari segi syariahnya (Muhammad, 2005).

Menurut Siswanto (2000) dalam Muslim (2012) terdapat beberapa faktor penyebab timbulnya kredit bermasalah diantaranya adalah ketidaklayakan debitur, salah urus (mismanagement), kurangnya pengetahuan dan pengalaman pemilik dalam bidang usaha bisnis yang dijalankan, adanya penipuan dari debitur, serta beberapa faktor ekstern lainnya seperti penurunan kondisi ekonomi moneter negara atau sektor usaha, debitur yang mengalami bencana alam (kebanjiran, banjir, gempa dll). Kashmir (2008) menyatakan, kemacetan kredit yang disebabkan oleh nasabah diakibatkan dua hal yaitu, adanya unsure kesengajaan artinya nasabah sengaja tidak mau membayar kewajibannya kepada bank sehingga kredit yang diberikan dengan sendirinya akan macet. Faktor yang kedua adalah unsure ketidaksengajaan dimana nasabah memiliki kemauan untuk membayar akan tetapi tidak mampu dikarenakan usaha yang dibiayainya terkena musibah. Supramono (1995) dalam Muslim (2012) lebih lanjut menjelaskan faktor yang mempengaruhi terjadinya kredit macet adalah berasal dari nasabah diantaranya adalah nasabah menyalahgunakan kredit yang diperolehnya, kemudian nasabah yang kurang mampu mengelolanya dan nasabah yang beritikad tidak baik. 
Salah satu faktor utama yang menyebabkan tidak adanya komitmen dari pihak nasabah pembiayaan untuk mematuhi akad yang telah dibuat dengan pihak perbankan adalah kurangnya pemahaman nasabah pembiayaan tentang akad yang telah dibuat dengan pihak bank syariah. Pada saat akad sedang berlangsung tidak sedikit nasabah tidak membaca syarat dan ketentuan yang ada pada surat perjanjian akad. Sehingga tidak sedikit pula yang melanggar ketentuan akad yang telah dibuat. Di sisi lain, masalah pembiayaan bermasalah juga dapat bersumber dari internal perbankan itu sendiri. Masalah tersebut antara lain adalah kurangnya pemahaman SDM perbankan syariah tentang akad-akad pembiayaan, kurangnya pemahaman SDM perbankan syariah tentang bisnis yang sedang biayai serta aspek hukumnya, kurangnya penerapan etika bisnis yang baik, kurangnya monitoring dan pengawasan, dan orientasi pada target (Devi, 2009).

Oleh karenanya, untuk mendapatkan dan atau mempertahankan kepercayaan masyarakat, industri perbankan harus diatur dan diawasi dengan ketat baik melalui peraturan langsung (direct regulation) maupun peraturan tidak langsung (indirect regulation). Peraturan langsung bertujuan mengurangi kewenangan pengurus bank dalam menjalankan kegiatan usaha. Bank misalnya dilarang memberikan kredit kepada suatu perusahaan melebihi prosentase tertentu dari modalnya. Sedangkan peraturan tidak langsung didasarkan pada pemberian insentif yang bertujuan mempengaruhi sikap tertentu dari pengurus bank, misalnya melalui penerapan peraturan mengenai persyaratan risk-based capital. Selain diawasi dengan baik, pemahaman akan akad-akad bermualah juga harus dipahami tidak hanya oleh pihak perbankan saja akan tetapi juga para nasabah pembiayaan, disamping itu mereka juga harus memiliki akhlak yang baik serta pemahaman akan etika berbisnis dalam Islam sehingga akad yang telah diperjanjikan sebelumnya dapat terlaksana dengan baik dan berdampak pada kurangnya risiko gagal bayar pada nasabah pembiayaan.

Berdasarkan uraian ini maka dapat dirumuskan beberapa rumusan masalah pada penelitian ini, adalah (1) Apa saja faktor-faktor yang mempengaruhi tingkat kepatuhan nasabah pembiayaan (komitmen) terhadap akad pembiayaan di bank syariah kota Bogor. (2) Bagaimana pengaruh penerapan komitmen akad terhadap pengembalian pembiayaan di bank syariah kota Bogor.

\section{Kajian Pustaka}

\subsection{Pembiayaan}

Menurut Muhammad (2002), pembiayaan (financing) atau pendanaan yang dikeluarkan untuk mendukung investasi yang telah direncanakan baik dilakukan sendiri maupun dijalankan oleh orang lain. Alokasi dana dalam bentuk pembiayaan memiliki beberapa tujuan yaitu mencapai tingkat profitabilitas yang cukup dan tingkat risiko yang rendah dan mempertahankan kepercayaan masyarakat dengan menjaga agar posisi likuidasi tetap aman. Sebagaimana dituangkan dalam pasal 1 (12) Undang-Undang No. 10 tahun 1988 tentang perbankan, dijelaskan bahwa pembiayaan berdasarkan prinsip syariah adalah penyediaan uang atau tagihan yang dipersamakan dengan itu berdasarkan persetujuan atau kesepakatan antara bank dengan pihak lain yang mewajibkan pihak yang dibiayai untuk mengembalikan uang atau tagihan tersebut setelah jangka waktu dengan imbalan atau bagi hasil. Karim (2008) mengungkapkan pembiayaan adalah salah satu tugas pokok bank, yaitu memberikan fasilitas yaitu pemberian fasiltias penyedia dana untuk memenuhi kebutuhan pihak yang defisit. 
Perjanjian pembiayaan merupakan landasan bagi para pihak untuk melakukan suatu prestasi, dimana nasabah sebagai pihak yang menerima dan mengelola dana pembiayaan, berkewajiban untuk melakukan suatu prestasi dan bank sebagai pihak pemberi dana mempunyai hak untuk menuntut prestasi dari nasabah. Prestasi ini berupa kewajiban nasabah untuk memenuhi dan melaksanakan semua ketentuan yang telah disepakati bersama dalam perjanjian pembiayaan, sedangkan bank telah memberikan dananya mempunyai hak untuk menuntuk nasabah agar melaksanakan dan mematuhi semua prestasi itu. Dengan adanya perjanjian yang dibuat oleh bank dengan nasabah, maka telah menimbulkan adanya hubungan hukum hukum yang berlandaskan pada aspek hukum perdata.

Pada saat melakukan akad pembiayaan kepada nasabah, pada umumnya bank akan menyediakan sebuah formulir berkenaan dengan perjanjian akad kredit tertentu sesuai dengan akad kredit yang akan diperjanjikan. Isi materi dari formulir perjanjian ini tentunya telah lebih dulu dipersiapkan oleh pihak bank. Formulir ini akan diserahkan kepada calon nasabah pembiayaan untuk disisi serta dimintai pendapatnya apakah ia mau menerima syarat-syarat yang telah tertulis dalam formulir perjanjian standar atau biasa dikenal sebahgai perjanjian adhesi.

Di dalam pasal 1320 KUHPerdata ditentukan tentang syarat-syarat sahnya perjanjian, yaitu:

1. Adanya kesepakatan antara mereka yang mengikatkan dirinya

2. Adanya kecakapan antara pihak-pihak untuk membuat suatu perjanjian

3. Ada suatu hal yang diperjanjikan dan jelas

4. Ada alasan yang halal mengapa sesuatu hal tersebut perlu untuk diperjanjikan.

Lebih lanjut dalam pasal 1321 KUHPerdata juga dinyatakan bahwa, "tidak sepakat yang sah apabila itu diberikan karena kekhilafan atau diperolehnya dengan paksaaan atau penipuan". Selanjutnya dalam pasal 1338 KUHPerdata mengandung suatu asas membuat perjanjian yang menganut sistem terbuka, dimana pasal tersebut menyatakan bahwa "semua persetujuan yang dibuat secara sah dan berlaku sebagai undang-undang bagi yang membuatnya".

\subsection{Komitmen Akad}

Komitmen merupakan hasrat atau keinginan kuat untuk mempertahankan dan melanjutkan relasi yang dipandang penting dan bernilai jangka panjang. Komitmen biasanya tercermin pada perilaku kooperatif dan tindakan aktif untuk tetap mempertahankan relasi yang telah terbina (Tjiptono, 2005). Komitmen adalah suatu sikap yang merupakan niat untuk mempertahankan keterhubungan jangka panjang karena hubungan tersebut dirasa berharga dan memberikan manfaat (Zarniwati, dkk, 2013). Sedangkan definisi komitmen menurut Morgan dan Hunt (1994) adalah:

"an exchange partner believing that on going relationship with another is so important as to warrant maximum efforts at maintaining it; that is, the committed party believes the relationship is worth working on to ensure that it endures indefinitely."

Adapun indikator pengukuran komitmen menurut Zarniwati, dkk (2012) adalah:

a. Bank melakukan penyesuaian sesuai dengan kebutuhan nasabah 
b. Bank menawarkan layanan untuk memenuhi kebutuhan nasabah

c. Bank fleksibel saat jasa perusahaan berubah

d. Bank mampu memenuhi janji

Morgan and Hunt (1994) menyatakan bahwa komitmen dipengaruhi oleh kepercayaan pelanggan. Konsumen yang mempercayai suatu perusahaan akan memiliki keyakinan yang tinggi terhadap perusahaan yang bersangkutan dan pada akhirnya akan berpengaruh terhadap komitmen pelanggan untuk menjalin hubungan jangka panjang dengan perusahaan. Pada pemasaran jasa yang menghasilkan produk tidak berwujud, efektifitas pemasaran jasa tergantung pada manajemen yang berdasarkan kepercayaan karena pada umumnya konsumen akan membeli jasa berdasarkan keyakinan bahwa mitra bisnisnya dapat dipercaya.

Keyakinan atau kepercayaan adalah suatu faktor penting yang dapat mengatasi krisi dan kesulitan antara rekan bisnis selain itu juga merupakan asset penting dalam mengembangkan hubungan jangka panjang antar organisasi (Zarniwati, dkk, 2013).. Menurut Zarniwati, dkk (2013) terdapat beberapa indikator pengukuran kepercayaan diantaranya adalah:

a. Bank sangat peduli dengan keamanan untuk transaksi

b. Bank dapat diandalkan

c. Bank konsisten dalam memberikan layanan yang berkualitas

d. Karyawan bank menunjukkan rasa hormat kepada pelanggan

e. Bank memenuhi kewajibannya terhadap nasabah

\subsection{Penggembalian Pembiayaan}

Pengembalian pembiayaan merupakan aspek penting yang perlu diperhatikan keberlangsungannya oleh pihak perbankan. Hal ini mengingat semakin baiknya pengembalian pembiayaan dalam suatu kegiatan operasional perbankan maka kegiatan perbankan dapat dikatakan sehat. Fungsi perbankan sebagai lembaga intermediasi tentunya harus memastikan bahwa kebutuhan dana deposan pada saat akan ditarik oleh nasabah deposan dapat terpenuhi kapanpun juga, yang artinya kebutuhan likuiditas perbankan tercukupi. Untuk memastikan kebutuhan likuiditas perbankan tercukupi, maka perbankan perlu melakukan monitoring dan pengawasan yang ketat dan baik pada dana yang tersalurkan dalam bentuk pembiayaan. Oleh karena itulah penyimpangan dan moral hazard tidak boleh terjadi pada aktifitas pembiayaan di perbankan syariah.

Perilaku penyimpangan atau moral hazard sangat erat sekali kaitannya dengan pengembalian pembiayaan. Artinya semakin besar potensi perilaku menyimpang yang dilakukan oleh baik dari nasabah pembiayaan maupun karyawan perbankan itu sendiri maka akan semakin besar potensi terjadinya kredit macet (pengembalian pembiayaan yang rendah). Dan sebaliknya, semakin rendah potensi perilaku menyimpang oleh nasabah dan karyawan bank, maka akan semakin kecil pula terjadinya kredit macet. Dalam perbankan, tinggi rendahnya pengembalian pembiayaan serta potensi terjadinya kredit bermasalah dapat dilihat pada rasio keuangan Non Performing Financing (NPF). Oleh sebab itulah dalam penelitian ini perilaku moral hazard dan segala faktor-faktor yang menyebabkan perilaku moral hazard tersebut terjadi menjadi proxy untuk mengukur potensi pengembalian pembiayaan dari nasabah kepada perbankan syariah (NPF). 
Menurut Rahman (2010), moral hazard diidentifikasikan sebagai segala bentuk kondisi ketika nasabah tidak mau dan atau tidak mampu menunaikan kewajiban membayar pokok modal dan bagi hasil sesuai dengan kesepakatan-antara bank dan nasabah- yang dilakukan di awal kontrak pembiayaan. Lebih lanjut Rahman (2010) mengungkapkan faktor-faktor yang menyebabkan terjadinya moral hazard pada nasabah pemibiayaan yang tentunya akan berpengaruh pada tinggi rendahnya tingkat pengembalian pembiayaan. Faktor-faktor tersebut antara lain:

1. Asymmetric Information merupakan faktor yang menyebabkan terjadinya moral hazard nasabah. Kepemilikan informasi yang tidak berimbang dimana nasabah memiliki informasi yang lebih lengkap tentang kondisi mereka daripada informasi yang dimiliki oleh bank menyebabkan nasabah mengambil keuntungan dari fasilitas pembiayaan yang mereka dapatkan yang pada akhirnya menyebabkan terjadinya moral hazard (NPF).

2. Karakter nasabah merupakan faktor penyebab terjadinya moral hazard nasabah. Lemahnya integritas manajerial atau rendahnya kualitas karakter nasabah seperti perilaku curang, kebohongan, dan keserakahan merupakan salah satu faktor yang mendasari berbagai kejadian moral hazard nasabah.

3. Terbatasnya cakupan isi kontrak merupakan faktor penyebab terjadinya moral hazard nasabah. Sempitnya penetapan kriteria moral hazard nasabah menyebabkan nasabah mudah untuk tergolong melakukan moral hazard, baik dari sudut pandang perbankan maupun dari sudut pandang fiqhiyyah. Sempitnya penetapan kriteria moral hazard tersebut pada akhirnya juga menyebabkan konflik keagenan antara pihak perbankan dan nasabah.

4. Tidak optimalnya sistem monitoring merupakan faktor penyebab terjadinya moral hazard nasabah. Kasus-kasus moral hazard yang terjadi pada perbankan syariah pada umumnya disebabkan oleh bank tidak bisa mengawasi (memonitor) secara optimal terhadap perilaku, kinerja dan kondisi nasbaah-terutama tentang kemampuan membayar- yang sesungguhnya, khususnya setelah kontrak pembiayaan berjalan.

\section{Metodologi Penelitian}

\subsection{Jenis dan Sumber Data Penelitian}

Data yang digunakan pada penelitian ini adalah data primer dan data sekunder. Data primer yang digunakan dalam penelitian ini diperoleh dari hasil kuesioner yang disebarkan kepada responden yang telah ditentukan sebagaimana teknik sampling diatas (yaitu nasabah yang melakukan akad pembiayaan di bank syariah di kota Bogor).

Data sekunder digunakan dalam penelitian ini diperoleh dari data pertumbuhan nasabah yang melakukan akad pembiayaan dengan prinsip bagi hasil di bank syariah di kota Bogor pada tahun 2013-2014.

Populasi pada penelitian ini adalah nasabah yang melakukan pembiayaan dengan prinsip bagi hasil di bank syariah di kota Bogor. Karena jumlah bank syariah di kota Bogor juga tidak sedikit dan berikut juga dengan jumlah nasabah pembiayaannya cukup banyak, maka sesuai dengan keterbatasan penelitian baik dari sisi waktu dan biaya maka tidak memungkinkan untuk 
diteliti seluruhnya. Oleh sebab itu, penelitian ini diteliti dengan penetapan metode sampling untuk memilih responden penelitian.

Sample merupakan bagian dari jumlah dan karakteristik yang dimiliki oleh populasi tersebut (Sugiyono, 2012). Sementara itu, sample pada penelitian ini adalah nasabah yang melakukan akad pembiayaan di bank syariah dengan menggunakan random sampling yakni pengambilan sample secara acak dengan menggunakan rumus Slovin (Umar, 2010). Rumus teknik sampling Slovin adalah:

$$
\begin{aligned}
& \mathrm{n}=\frac{N}{1+N \cdot e^{2}} \ldots \\
& \text { dimana: }
\end{aligned}
$$

$\mathrm{n}=$ ukuran sampel

$N=$ ukuran populasi

$e=$ Prosentase kelonggaran ketidaktentuan karena kesalahan pengambilan sampel yang masih diinginkan, dalam penelitian ini digunakan $e=10 \%$

\subsection{Kerangka Pemikiran}

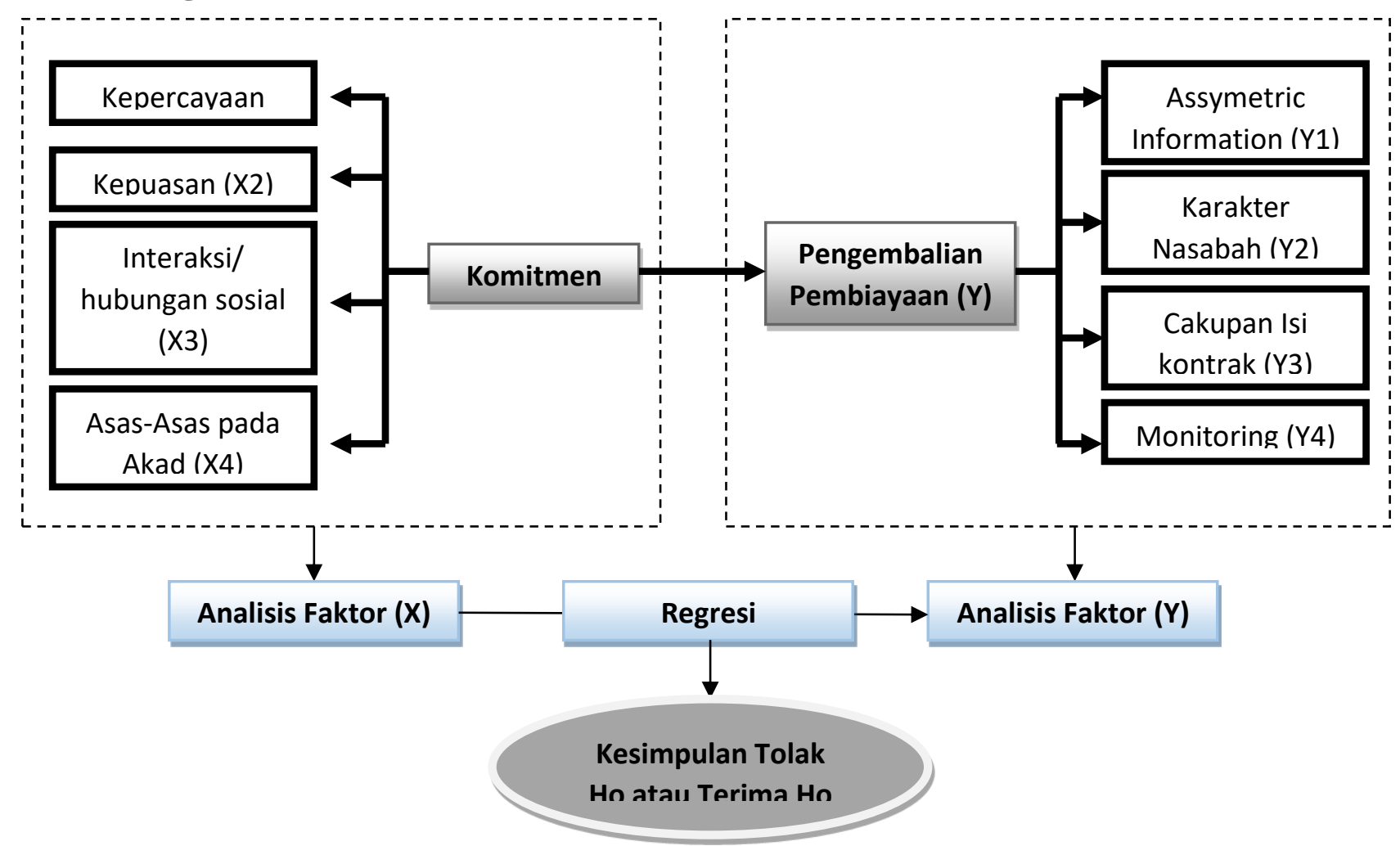

Gambar 2. Kerangka Pemikiran

Kerangka pemikiran diatas sebagaimana terangkum dalam gambar 2 menjelaskan alur pemikiran peneliti serta tujuan penelitian yang ingin diangkat. Sebagaimana telah dibahas pada bab 1 ada dua tujuan penelitian ini dimana tujuan pertama adalah untuk menganalisis faktorfaktor apa saja yang berpengaruh terhadap komitmen akad dan pengembalian pembiayaan. Setelah melakukan literature review dan kajian pustaka pada bab 2, maka diperoleh empat faktor pada masing-masing variabel ( $\mathrm{X}$ dan $\mathrm{Y}$ ) dimana dari keempat faktor tersebut nantinya 
akan dianalisis dengan menggunakan metodologi analisis faktor untuk melihat faktor-faktor apa saja yang mempengaruhi variabel komitmen dan pengembalian pembiayaan.

Selanjutnya, pada tahap selanjutnya sesuai dengan tujuan penelitian yaitu untuk melihat apakah ada hubungan dan pengaruh antara variabel $\mathrm{X}$ (komitmen) dan variabel $\mathrm{Y}$ (pengembalian pembiayaan) di bank syariah. Untuk menjawab tujuan penelitian yang kedua maka digunakan metode regresi linier sederhana.

\subsection{Definisi Operasional Variabel}

Tabel 1. Definisi Operasional variabel

\begin{tabular}{|c|c|c|c|c|c|}
\hline $\begin{array}{c}\text { Variabel dan } \\
\text { Definisi } \\
\text { operasional } \\
\text { variabel }\end{array}$ & $\begin{array}{c}\text { Faktor- } \\
\text { Faktor yang } \\
\text { Mempengaru } \\
\text { hi (indikator) }\end{array}$ & $\begin{array}{c}\text { Definisi Operasional } \\
\text { Indikator }\end{array}$ & Item & $\begin{array}{c}\text { Definisi } \\
\text { Operasional Item }\end{array}$ & Sumber \\
\hline \multirow{8}{*}{$\begin{array}{l}\text { Komitmen }(\mathbf{X}) \\
=\text { hasrat atau } \\
\text { keinginan kuat } \\
\text { untuk } \\
\text { mempertahankan } \\
\text { dan melanjutkan } \\
\text { relasi yang } \\
\text { dipandang } \\
\text { penting dan } \\
\text { bernilai jangka } \\
\text { panjang }\end{array}$} & \multirow{3}{*}{$\begin{array}{l}\text { Kepercayaan } \\
\text { Pelanggan } \\
\text { (X1) }\end{array}$} & \multirow{3}{*}{$\begin{array}{l}\text { Konsumen yang } \\
\text { mempercayai suatu } \\
\text { perusahaan akan } \\
\text { memiliki keyakinan yang } \\
\text { tinggi terhadap } \\
\text { perusahaan yang } \\
\text { bersangkutan dan pada } \\
\text { akhirnya akan } \\
\text { berpengaruh terhadap } \\
\text { komitmen pelanggan } \\
\text { untuk menjalin hubungan } \\
\text { jangka panjang dengan } \\
\text { perusahaan. }\end{array}$} & Dipercaya & $\begin{array}{l}\text { Karyawan dapat } \\
\text { dipercaya }\end{array}$ & \multirow[t]{3}{*}{$\begin{array}{l}\text { Morgan and } \\
\text { Hunt (1994) }\end{array}$} \\
\hline & & & $\begin{array}{l}\text { Keterandala } \\
\mathrm{n}\end{array}$ & $\begin{array}{l}\text { Bank dapat } \\
\text { diandalkan }\end{array}$ & \\
\hline & & & Integritas & $\begin{array}{l}\text { Karyawan bank } \\
\text { memiliki integritas }\end{array}$ & \\
\hline & \multirow{3}{*}{$\begin{array}{l}\text { Kepuasan } \\
\text { Pelanggan } \\
\text { (X2) }\end{array}$} & \multirow{3}{*}{$\begin{array}{l}\text { Kepuasan pelanggan } \\
\text { dapat terlihat dari } \\
\text { seberapa baik pelayanan } \\
\text { yang diberikan oleh } \\
\text { perusahaan }\end{array}$} & Kualitas & $\begin{array}{l}\text { Puas terhadap } \\
\text { kualitas produk/jasa }\end{array}$ & \multirow{3}{*}{$\begin{array}{l}\text { Hennig- } \\
\text { Thurau et al } \\
(2002) \text {; } \\
\text { Boonajsevee } \\
(2005)\end{array}$} \\
\hline & & & Harga & $\begin{array}{l}\text { Puas terhadap harga } \\
\text { produk/jasa }\end{array}$ & \\
\hline & & & Pelayanan & $\begin{array}{l}\text { Puas terhadap } \\
\text { kualitas layanan }\end{array}$ & \\
\hline & $\begin{array}{l}\text { Interaksi/hubu } \\
\text { ngan Sosial } \\
\text { (X3) }\end{array}$ & \multirow[t]{2}{*}{$\begin{array}{l}\text { interaksi sosial yang } \\
\text { terjadi antara nasabah } \\
\text { dan karyawan akan } \\
\text { menimbulkan } \\
\text { pemahaman mengenai } \\
\text { masing-masing pihak } \\
\text { sehingga dapat membuat } \\
\text { kedua belah pihak saling } \\
\text { memahami sehingga } \\
\text { dapat membantu } \\
\text { menghindari } \\
\text { kesalahpahaman, } \\
\text { menghindari penolakan } \\
\text { untuk bekerja sama atau } \\
\text { akibat lainnya yang dapat } \\
\text { menyebabkan kegagalan } \\
\text { hubungan kerjasama } \\
\text { antara kedua belah pihak }\end{array}$} & Komunikasi & $\begin{array}{l}\text { berbagi informasi } \\
\text { bermakna dan tepat } \\
\text { waktu antara } \\
\text { perusahaan dan } \\
\text { pelanggan, baik } \\
\text { secara formal } \\
\text { maupun informal. } \\
\text { Komunikasi, } \\
\text { khususnya } \\
\text { komunikasi yang } \\
\text { tepat waktu dapat } \\
\text { mempercepat } \\
\text { kepercayaan dengan } \\
\text { membantu } \\
\text { penyelesaian } \\
\text { perselisihan dan } \\
\text { menyamakan } \\
\text { persepsi dan } \\
\text { harapan pelangan- } \\
\text { perusahaan }\end{array}$ & \multirow[t]{2}{*}{$\begin{array}{l}\text { Bendapuli } \\
\text { and Leone } \\
(2002)\end{array}$} \\
\hline & & & Familiarity & $\begin{array}{l}\text { tingkat pengakuan } \\
\text { personal pelanggan }\end{array}$ & \\
\hline
\end{tabular}


Vol. 9 No. 2, December 2018

\begin{tabular}{|c|c|c|c|c|}
\hline & & & $\begin{array}{l}\text { oleh karyawan } \\
\text { persuahaan sebagai } \\
\text { hasil dari interaksi } \\
\text { dalam beberapa } \\
\text { waktu }\end{array}$ & \\
\hline \multirow[t]{7}{*}{$\begin{array}{l}\text { Asas-Asas } \\
\text { pada Akad } \\
\text { (X4) }\end{array}$} & \multirow[t]{7}{*}{$\begin{array}{l}\text { Terpenuhinya asas-asas } \\
\text { yang menjadi landasand } \\
\text { alam berakad. }\end{array}$} & $\begin{array}{l}\text { Ikhtiyari/suk } \\
\text { arela; }\end{array}$ & $\begin{array}{lr}\text { setiap } & \text { akad } \\
\text { dilakukan atas } \\
\text { kehendak para } \\
\text { pihak, terhindar dari } \\
\text { keterpaksaan karena } \\
\text { tekanan salah satu } \\
\text { pihak atau pihak } \\
\text { lain. }\end{array}$ & \multirow[t]{7}{*}{$\begin{array}{l}\text { Kompilasi } \\
\text { Hukum } \\
\text { Ekonomi } \\
\text { Syariah }\end{array}$} \\
\hline & & $\begin{array}{l}\text { Amanah/me } \\
\text { nepati janji; }\end{array}$ & $\begin{array}{l}\text { setiap akad wajib } \\
\text { dilaksanakan oleh } \\
\text { para pihak sesuai } \\
\text { dengan kesepakatan } \\
\text { yang ditetapkan } \\
\text { oleh yang } \\
\text { bersangkutan dan } \\
\text { pada saat yang sama } \\
\text { terhindar dari cidera } \\
\text { janji. }\end{array}$ & \\
\hline & & $\begin{array}{l}\text { Ikhtiyati/keh } \\
\text { ati-hatian; }\end{array}$ & $\begin{array}{lr}\text { setiap } & \text { akad } \\
\text { dilakukan dengan } \\
\text { pertimbangan yang } \\
\text { matang dan } \\
\text { dilaksanakan secara } \\
\text { tepat dan cermat. } \\
\end{array}$ & \\
\hline & & $\begin{array}{l}\text { Luzum/tidak } \\
\text { berubah; }\end{array}$ & $\begin{array}{lr}\text { setiap } & \text { akad } \\
\text { dilakukan dengan } \\
\text { tujuan yang jelas } \\
\text { dan perhitungan } \\
\text { yang } & \text { cermat, } \\
\text { sehingga } & \text { terhindar } \\
\text { dari } & \text { praktik } \\
\text { spekluasi } & \text { atau } \\
\text { maysir. } & \end{array}$ & \\
\hline & & $\begin{array}{l}\text { Saling } \\
\text { menguntung } \\
\text { kan; }\end{array}$ & $\begin{array}{lr}\text { setiap } & \text { akad } \\
\text { dilakukan } & \text { untuk } \\
\text { memenuhi } & \\
\text { kepentingan para } \\
\text { pihak } & \text { sehingga } \\
\text { tercegah } & \text { dari } \\
\text { praktik } & \text { manipulasi } \\
\text { dan } & \text { merugikan } \\
\text { salah satu pihak. }\end{array}$ & \\
\hline & & $\begin{array}{l}\text { Taswiyah/ke } \\
\text { setaraan; }\end{array}$ & $\begin{array}{lr}\text { para pihak } & \text { dalam } \\
\text { setiap } & \text { akad } \\
\text { memiliki } & \\
\text { kedudukan } & \text { yang } \\
\text { setara, } & \text { dan } \\
\text { mempunyai hak dan } \\
\text { kewajiban yang } \\
\text { seimbang }\end{array}$ & \\
\hline & & $\begin{array}{l}\text { Kemampuan } \\
\text {; }\end{array}$ & $\begin{array}{lr}\text { setiap } & \text { akad } \\
\text { dilakukan } & \text { sesuai } \\
\text { dengan } & \\
\text { pertanggungjawaba }\end{array}$ & \\
\hline
\end{tabular}


Vol. 9 No. 2, December 2018

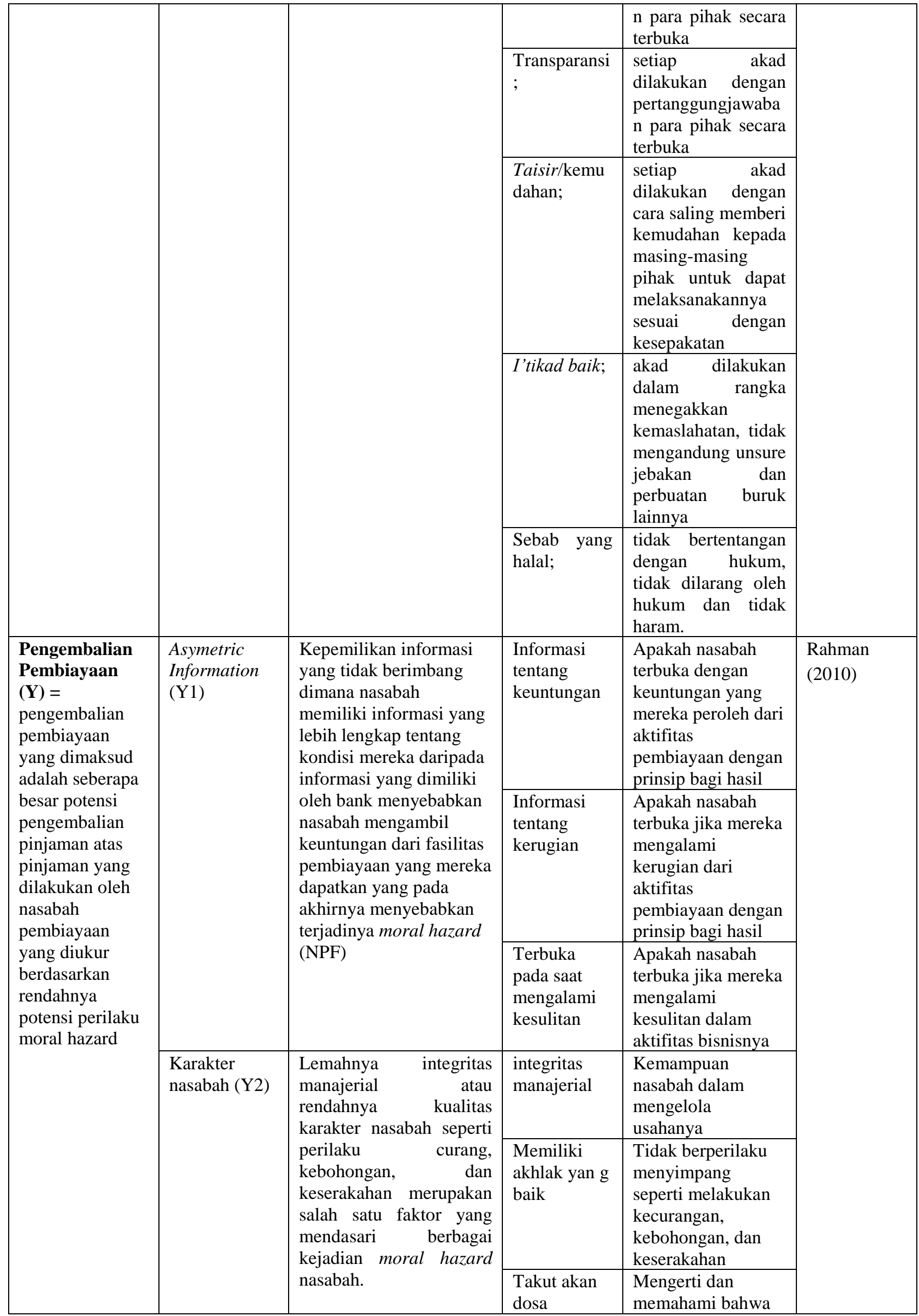


Vol. 9 No. 2, December 2018

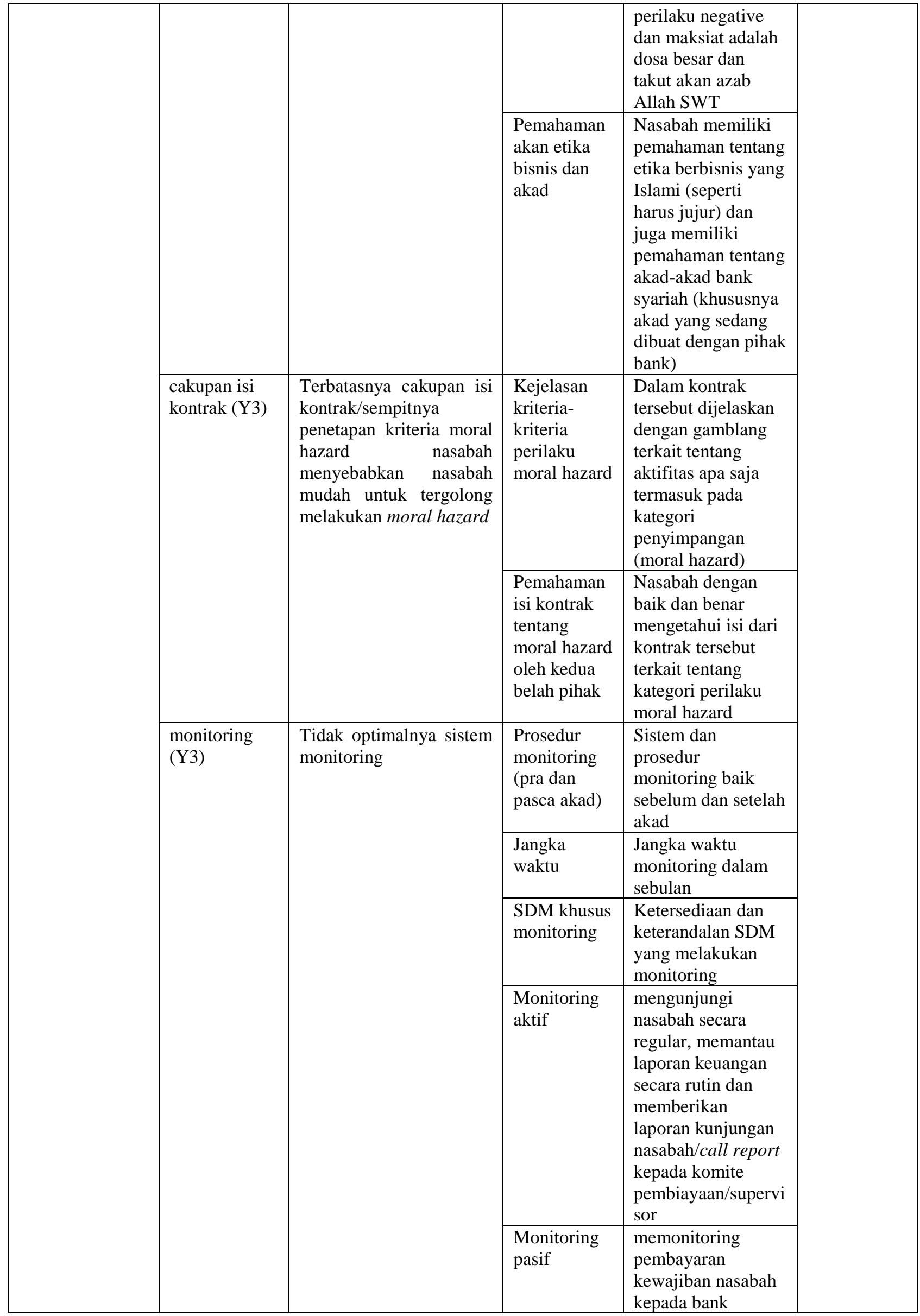




\begin{tabular}{|l|l|l|l|}
\hline & & & $\begin{array}{l}\text { syariah setiap akhir } \\
\text { bulan. Bersamaan } \\
\text { pula diberikan } \\
\text { pembinaaan dengan } \\
\text { memberikan saran, } \\
\text { informasi maupun } \\
\text { pembinaan tehnis } \\
\text { yang bertujuan } \\
\text { untuk menghindari } \\
\text { pembiayaan } \\
\text { bermasalah. }\end{array}$ \\
\hline
\end{tabular}

Sumber: Data Sekunder Olah data Peneliti

\subsection{Hipotesis}

Dalam penelitian ini, maka hipotesis yang diajukan dan akan diuji adalah:

H0: tidak terdapat pengaruh antara komitmen pada akad terhadap pengembalian pembiayaan oleh nasabah

H1: terdapat pengaruh antara komitmen pada akad terhadap pengembalian pembiayaan oleh nasabah

\section{Hasil dan Pembahasan}

\subsection{Uji Asumsi Klasik}

\subsubsection{Uji Normalitas}

Uji normalitas pada model regresi digunakan untuk menguji apakah nilai residual terdistribusi secara normal atau tidak. Jadi, dalam hal ini yang diuji normalitas bukan masingmasing variabel independen dan dependen tetapi nilai residual yang dihasilkan dari model regresi (Priyatno, 2011).

\section{Normal P-P Plot of Regression Standardized Residual}

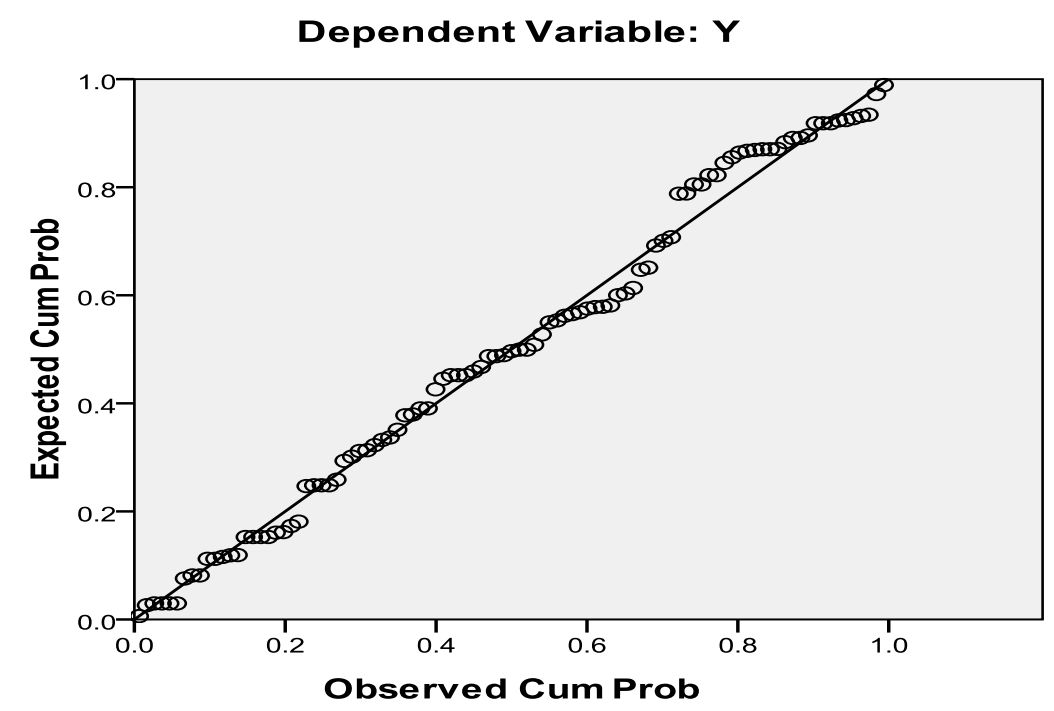

Gambar 3. Hasil Uji Normalitas 
Berdasarkan grafik di atas, dapat diketahui bahwa titik-titik menyebar disekitar garis dan mengikuti garis diagonal maka residual pada model regresi tersebut terdistribusi secara normal.

\subsubsection{Uji Multikolinearitas}

Uji multikolinearitas digunakan untuk menguji apakah model regresi ditemukan adanya korelasi antar variabel independen. Model regresi yang baik maka seharusnya tidak terjadi korelasi diantara variabel bebas. Metode pengujian yang biasa digunakan yaitu dengan melihat nilai Inflation Factor (VIF) dan tolerance pada model regresi. Jika nilai VIF kurang dari 10 dan tolerance lebih dari 0,1 maka model regresi bebas dari multikolinearitas (Priyatno, 2011).

Tabel 2. Hasil Uji Multikolinearitas

Coefficients $^{a}$

\begin{tabular}{|c|c|c|c|c|c|c|c|}
\hline \multirow[b]{2}{*}{ Model } & \multicolumn{2}{|c|}{$\begin{array}{l}\text { Unstandardized } \\
\text { Coefficients }\end{array}$} & \multirow{2}{*}{\begin{tabular}{|c|}
$\begin{array}{c}\text { Standardized } \\
\text { Coefficients }\end{array}$ \\
Beta
\end{tabular}} & \multirow[b]{2}{*}{$t$} & \multirow[b]{2}{*}{ Sig. } & \multicolumn{2}{|c|}{ Collinearity Statistics } \\
\hline & $B$ & Std. Error & & & & Tolerance & VIF \\
\hline $1 \quad$ (Constant) & -.752 & .829 & & -.907 & .367 & & \\
\hline$x$ & .939 & .062 & .839 & 15.204 & .000 & 1.000 & 1.000 \\
\hline
\end{tabular}

a. Dependent Variable: $Y$

Sumber: Olah Data SPSS

Berdasarkan tabel 11 di atas dapat diketahui bahwa nilai VIF kurang dari 10 dan nilai tolerance lebih dari 0,1 untuk ketiga variabel maka dapat disimpulkan bahwa model regresi tidak terjadi masalah multikolinearitas.

\subsubsection{Uji Auto Korelasi}

Uji autokorelasi digunakan untuk menguji apakah model regresi ada korelasi antara residual pada periode $t$ dengan residual pada periode ( $\mathrm{t}-1)$. Model regresi yang baik adalah yang tidak adanya masalah autokorelasi. Pada penelitian ini metode pengujian yang digunakan adalah dengan uji Durbin-Watson (DW) (Priyatno, 2011).

Tabel 3. Hasil Uji Durbin-Watson 
Vol. 9 No. 2, December 2018

\begin{tabular}{|l|r|r|c|r|r|}
\hline Model & R & R Square & $\begin{array}{c}\text { Adjusted R } \\
\text { Square }\end{array}$ & $\begin{array}{c}\text { Std. Error of the } \\
\text { Estimate }\end{array}$ & Durbin-Watson \\
\hline 1 & $.839^{\mathrm{a}}$ & .704 & .701 & 1.40359 & 1.245 \\
\hline
\end{tabular}

a. Predictors: (Constant), $\mathrm{X}$

b. Dependent Variable: $Y$

Sumber: Olah Data SPSS

Nilai Durbin-Watson dapat dilihat pada output regression pada tabel di atas. Tabel di atas menunjukkan bahwa nilai Durbin-Watson sebesar 1.245. Sedangkan pada tabel DW dengan signifikansi 0,05 dan jumlah data $(n)=99$, serta jumlah variabel independen $(k)=1$, maka diperoleh nilai sebesar $\mathrm{dl}=1.442 \mathrm{dan} \mathrm{du}=1.544$. Dengan ini maka didapat 4 -du $=2.466$. Karena nilai dw (1.245) maka nilai dw berada diantara du dan 4-du, maka Ho diterima, dan dapat disimpulkan bahwa tidak terjadi autokorelasi pada model regresi.

\subsubsection{Uji Heteroskedatisitas}

Uji heteroskedastisitas digunakan untuk menguji apakah dalam model regresi terjadi ketidaksamaan varian dari residual pada satu pengamatan ke pengamatan yang lain. Model regresi yang baik adalah tidak terjadi heteroskedastisitas. Pada penelitian ini uji heteroskedastisitas menggunakan uji korelasi Spearman.

\section{Scatterplot}

\section{Dependent Variable: $Y$}

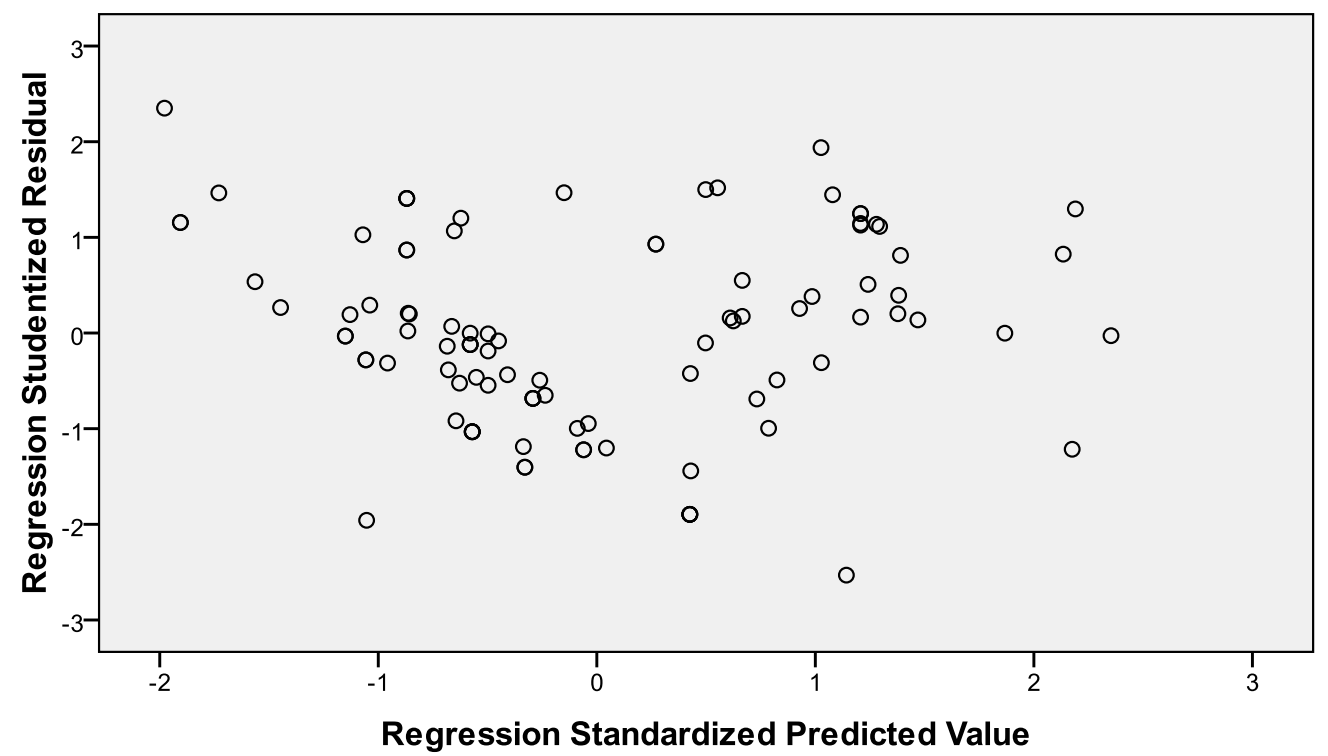

Gambar 4. Hasil Heteroskedastisitas

Sumber: Olah Data SPSS

Berdasarkan output di atas pada gambar scatterplot, maka dapat dilihat bahwa titik-titik menyebar dengan pola yang tidak jelas di atas dan di bawah angka 0 pada sumbu Y. Sehingga dapat disimpulkan bahwa pada model regresi tidak ada masalah heteroskedastisitas. 


\subsection{Uji Hipotesis Regresi Linear Sederhana}

Setelah melakukan beberapa uji asumsi klasik yang merupakan prasyarat sebelum melakukan uji hipotesis regresi linier, maka pada sub-bab kali ini akan dibahas hasil dari uji hipotesis terkait model regresi yang diangkat pada penelitian ini.

Tabel 4. Hasil Uji Korelasi

\begin{tabular}{|ll|r|r|}
\hline \multicolumn{1}{|c|}{ Correlations } \\
\hline & & $Y$ & \multicolumn{1}{|c|}{$X$} \\
\hline Pearson Correlation & $Y$ & 1.000 & .839 \\
& $\mathrm{X}$ & .839 & 1.000 \\
\hline Sig. (1-tailed) & $\mathrm{Y}$ &. & .000 \\
& $\mathrm{X}$ & .000 & \\
\hline $\mathrm{N}$ & $\mathrm{Y}$ & 99 & 99 \\
& $\mathrm{X}$ & 99 & 99 \\
\hline
\end{tabular}

Sumber: Olah Data SPSS

Hasil uji korelasi pada tabel di atas menunjukkan besarnya hubungan antara variabel Y (pengembalian pembiayaan) dengan variabel X1 (komitmen akad) adalah 0,839. Nilai ini berarti bahwa hubungan kedua variabel tersebut adalah tinggi. Koefisien korelasi positif $(0,839)$ menunjukkan bahwa hubungan antara variabel pengembalian pembiayaan dan komitmen akad adalah searah. Artinya, jika seseorang memiliki komitmen atas akad yang telah dibuat dengan pihak bank, maka pengembalian pembiyaan juga akan semakin baik. Hubungan antara komitmen atas akad dan pengembalian pembiyaan adalah signifikan sebagaimana ditunjukkan dengan angka signifikansi (sig.) sebesar 0,000 yang lebih kecil dari 0,05.

Untuk menguji hipotesis, pengujian dilakukan dengan menggunakan koefisien determinasi $\left(\mathrm{R}^{2}\right)$. Koefisien determinasi memiliki fungsi untuk menjelaskan sejauh mana kemampuan variabel independen (X1 [komitmen atas akad]) berpengaruh terhadap variabel dependen (Y [pengembalian pembiayaan]).

Tabel 5. Hasil Uji Koefisien Determinasi

\begin{tabular}{|l|r|r|r|r|r|}
\hline \multicolumn{1}{|c|}{} & Model Summary \\
\hline 1 & $\mathrm{R}$ & R Square & $\begin{array}{c}\text { Adjusted R } \\
\text { Square }\end{array}$ & $\begin{array}{l}\text { Std. Error of the } \\
\text { Estimate }\end{array}$ & Durbin-Watson \\
\hline 1 & $.839 \mathrm{a}$ & .704 & .701 & 1.40359 & 1.245 \\
\hline
\end{tabular}
a. Predictors: (Constant), $\mathrm{X}$
b. Dependent Variable: $Y$

Sumber: Olah Data SPSS

Berdasarkan tabel di atas, nilai R square adalah 0,704. Angka R square atau koefisien determinasi sebesar 0,704 atau 70,4\% menunjukkan bahwa 70,4\% pengembalian pembiayaan dapat dijelaskan dengan menggunakan variabel komitmen akad. Sedangkan sisanya 29,6\% dijelaskan oleh faktor-faktor lainnya. 
Vol. 9 No. 2, December 2018

Tabel 6. Hasil Anova (uji F)

\begin{tabular}{|c|c|c|c|c|c|c|}
\hline \multicolumn{7}{|c|}{ ANOVA $^{\mathrm{b}}$} \\
\hline & & Sum of Squares & $d f$ & Mean Square & $\mathrm{F}$ & Sig. \\
\hline \multirow[t]{3}{*}{1} & Regression & 455.414 & 1 & 455.414 & 231.168 & $.000^{\mathrm{a}}$ \\
\hline & Residual & 191.096 & 97 & 1.970 & & \\
\hline & Total & 646.510 & 98 & & & \\
\hline
\end{tabular}

a. Predictors: (Constant), $X$

b. Dependent Variable: $Y$

Sumber: Olah Data SPSS

Tabel diatas menunjukkan hasil uji Anova yang menghasilkan angka F sebesar 231.168 dengan tingkat signifikansi sebesar 0,000. Karena angka probabilitas $0,000<0,05$, maka dapat disimpulkan bahwa model regresi ini sudah layak digunakan untuk memprediksi tingkat pengembalian pembiayaan. Maka Ho ditolak dan H1 diterima, dimana variabel komitmen akad berpengaruh terhadap pengembalian pembiayaan.

Tabel 7. Hasil Koefisien Regresi (uji t)

\begin{tabular}{|c|c|c|c|c|c|c|c|}
\hline \multicolumn{8}{|c|}{ Coefficients $^{a}$} \\
\hline \multirow[b]{2}{*}{ Model } & \multicolumn{2}{|c|}{$\begin{array}{c}\text { Unstandardized } \\
\text { Coefficients }\end{array}$} & \multirow{2}{*}{$\begin{array}{c}\begin{array}{c}\text { Standardized } \\
\text { Coefficients }\end{array} \\
\text { Beta }\end{array}$} & \multirow[b]{2}{*}{$\mathrm{t}$} & \multirow[b]{2}{*}{ Sig. } & \multicolumn{2}{|c|}{ Collinearity Statistics } \\
\hline & $\mathrm{B}$ & Std. Error & & & & Tolerance & VIF \\
\hline $1 \quad$ (Constant) & -.752 & .829 & & -.907 & .367 & & \\
\hline$x$ & .939 & .062 & .839 & 15.204 & .000 & 1.000 & 1.000 \\
\hline
\end{tabular}

a. Dependent Variable: $Y$

Sumber: Olah Data SPSS

Pada bagian koefisien regresi menggambarkan persamaan regresi untuk mengetahui angka konstan dan uji hipotesis signifikansi koefisien regresi. Oleh karenanya persamaan regresi pada penelitian ini adalah:

$$
\mathrm{Y}=\mathbf{- 0 . 7 5 2}+\mathbf{0 , 9 3 9} \mathrm{X1}
$$

Angka konstan pada penelitian ini adalah sebesar -0.752 yang berarti bahwa pengembalian pembiayaan (Y) memiliki angka -0.752 apabila nilai X (komitmen akad) adalah sama dengan 0. Koefisien regresi X (komitmen akad) menunjukkan angka 0,939 yang berarti bahwa setiap kenaikan 1 persen komitmen akad maka akan meningkatkan pengembalian pembiayaan sebesar 0.939 persen dengan tingkat signifikansi sebesar 15.204 (t hitung) $>2.052$ (t tabel) maka H0 ditolak dan $\mathrm{H} 1$ diterima. Yang berarti bahwa terdapat pengaruh positif dan signifikan komitmen akad terhadap pengembalian pembiayaan. 


\section{Kesimpulan}

Berdasarkan pembahasan sebelumnya maka kesimpulan pada penelitian ini adalah, sebagai berikut:

1. Pada analisis regresi linear sederhana di ketahui, bahwa kepercayaan, komitmen hubungan social, dan huukum yang jelas pada akad memiliki faktor terhadap komitmen nasabag dalam mebaayar pembiayaan. Dengan nilai $\mathrm{R}$ square adalah 0,704. Angka $\mathrm{R}$ square atau koefisien determinasi sebesar 0,704 atau 70,4\% menunjukkan bahwa 70,4\% pengembalian pembiayaan dapat dijelaskan dengan menggunakan variabel komitmen akad. Sedangkan sisanya 29,6\% dijelaskan oleh faktor-faktor lainnya.

2. Pada anailis regresi linear sederhana, diketahui ingkat signifikansi sebesar $15.204(\mathrm{t}$ hitung) > 2.052 ( t tabel) maka H0 ditolak dan H1 diterima. Yang berarti bahwa terdapat pengaruh positif dan signifikan komitmen akad terhadap pengembalian pembiayaan.

\section{Referensi}

Ali, H. Masyhud (2004). Asset Liability Management. Jakarta: PT. Elex Media Komputindo.

Bendapuli, Neeli., Robert P. Leone (2002). Managing business to Costumer Relationships: Following Key Contact Employee Turnover in Vendor Firm. Journal of Marketing. Vol. 66 No.2.

Boonajsevee, Bhoomipan (2005). Relationship Marketing: Loyalty Intentions in New Era of Thai Bank Marketing. Dissertation. The Wayne Huizenga Graduate School of Business and Entrepreneurship. Nova Souteastern University.

Devi, Abrista (2009). Analisis Faktor-Faktor yang Mempengaruhi tidak Diterapkannya Pembiayaan Akad Bai' Al-Salam di Perbankan Syariah di Indonesia. Jurusan Manajemen Bisnis Islam STEI TAZKIA.

Hennig-Thurau, T., Kevin P. Gwinner., Dwayne D. Gremier (2002). Understanding Relationship Outcomes: An Integration of Relational Benefits and Relationship Quality. Journal of Service Research. Vol. 4 No. 3.

Karim, Adiwarman A (2008). Bank Islam: Analisis Fiqh dan Keuangan. Edisi 3. Jakarta: PT Raja Grafindo Persada.

Kasmir (2008). Bank dan Lembaga Keuangan Lainnya. Jakarta: Raja Grafindo.

Kompilasi Hukum Ekonomi Syariah. Retrieved from Eksklusive www.badilag.net

Morgan, Robert M., Sehelby D. Hunt (1994). The Commitment-Trust Theory of Relationship Marketing. Journal of Marketing. Vol. 58 No.3.

Morgan, Robert M (2000). Relationship Marketing and Marketing Strategy: The Evolution of Relationship Marketing within the Organization. Handbook of Relationship Marketing. Jagdish.N.Sheth and Atul Parvatiyar. Sage Publication, Inc. London.

Muhammad (2002). Bank Syariah Analisis Kekuatan, Kelemahan, Peluang dan Ancaman. Yogyakarta: Ekonosia.

Muhammad (2005). Manajemen Pembiayaan Bank Syariah. Yogyakarta: UPP AMP YKPN. Muslim (2012). Analisis Faktor-Faktor yang Mempengaruhi Kredit Macet (Kurang Lancar, diragukan, dan Macet) Pada UMKM Industri Mebel di Kabupaten Jepara Tahun 2012. Fakultas Ekonomika dan Bisnis Universitas Diponegoro. Semarang.

Rahman, Andy Fathur (2010). Analisis Faktor yang Menyebabkan Terjadinya Moral Hazard Nasabah Pembiayaan Mudharabah (Studi Penelitian di BTN Syariah Cabang Solo). Tesis. Program Pascasarjana UIN Sunan Kalijaga. Yogyakarta

Siamat, Dahlan (2005). Manajemen Lembaga Keuangan. Edisi Kelima. Jakarta: Lembaga Penerbit FEUI.

Umar, H (2010). Riset Pemasaran dan Perilaku Konsumen. Jakarta: PT Gramedia Pustaka Utama. 
Vol. 9 No. 2, December 2018

Zarniwati, Eka., Wendi Boy, ST.MM., Yulasmi, SE. MM., (2013). Analisis Pengaruh Kepercayaan, Komitmen, Komunikasi, dan Penanganan Keluhan terhadap Loyalitas Nasabah (Studi Pada Nasabah PT.BNI (Persero) Tbk. Cabang Padang).

UU RI no. 10 tahun 1998, tanggal 10 November 1998

Undang-Undang No. 10 tahun 1988 tentang perbankan

Undang-Undang Republik Indonesia No.21 tahun 2008 tentang Perbankan Syariah www.bi.gi.id

Dwi Priyatno, Buku Saku SPSS; Analisis Statistik Data Lebih Cepat Efisien dan Akurat. Yogyakarta: Mediacom, 2011 